\title{
The Role of Indonesian CSOs in Increasing the Understanding of Disabled Issues in the Indonesian Criminal Justice System
}

\author{
Dio Ashar Wicaksana, Indonesian Judicial Monitoring Society - Faculty of Law \\ University of Indonesia, Indonesia
}

\begin{abstract}
Indonesia successfully amended Disabled People Law in early 2016. The fundamental amendment is creating equal rights and opportunity for disabled groups. Disability group in this context is the people who have physical and mental limitations to communicate and participate effectively with another people as equals. But, nowadays some people prefer using the term "disabled" than "disabled".

Disabled alongside with feminist, LGBT and minority groups commonly known as a part of discriminated groups in society. Disabled activist believe that disabled is a natural part of human diversity - something that should be valued and respected, rather than pitied, feared and discriminated. Disabled people are potentially to be victim 4-10 times more than other people. Pusham UII (2015) highlighted the existence of many violations in the Indonesian criminal justice system to disabled people, such as: improper questioning, failure to process reports from blind people and a general atmosphere of disrespect to the disabled community. One of the major problems is the Indonesian law officers' lack of knowledge and understanding of disabled groups.

In Yogyakarta, Civil Society Organization (CSO) has significant role to increase understanding of disabled issues. In this instance, Sasana Integration and Advocacy of Disabled (Sigab) developed an inclusive village project in Yogyakarta. They provide education and socialization of disabled issues within village's community. Another example, Pusham UII have developed the curriculum and module to provide training in legal institution (Police, Prosecutor and Judge).

This paper discusses the understanding of law officer after Indonesian disability law already enacted in early 2016. Thereafter, I will discuss how Indonesian CSOs helps to increase the understanding of disabled issues, to eliminate gap of knowledge between legal formal with practice area. Consequently, my research question is formulated: "How does the role of Indonesian CSOs to increase the understanding of disabled issues in the Indonesian criminal justice system?"
\end{abstract}

Keywords: Disability, Civil Society Organization, Criminal Justice System

\section{INTRODUCTION}

Indonesia successfully amended the Disabled People Law in early 2016, and it was following the ratification of Convention on the Rights of Persons with Disabilities 
(CRPD) in 2011. This amendment was fundamentally recognizing equal rights and opportunity for disabled groups ${ }^{1}$. This law also reconstructs the term of impairment for disability groups - disability groups in this context are the people who have physical and mental limitations to communicate and participate effectively with another people as equals. ${ }^{2}$ But, Indonesian currently activist are promoting the use of the term "disabled" instead of "disabled". The term disabled comes from "differently abled", it has different implications to disability, which translates into effect to 'inability'.

Disabled alongside with feminist, LGBT and minority groups commonly known as a part of discriminated groups in society. Disabled activist believe that disabled is a natural part of human diversity - something that should be valued and respected, rather than pitied, feared and discriminated. Disabled people are potentially to be victim 4-10 times more than other people. Pusham UII (2015) highlighted the existence of many violations in the Indonesian criminal justice system to disabled people, such as: improper questioning, failure to process reports from blind people and a general atmosphere of disrespect to the disabled community. One of the major problems is the Indonesian law officers' lack of knowledge and understanding of disabled groups.

Notwithstanding, Indonesian law already established equality and new perspective to disabled people, however, the implementation is not successfully well-implemented in practice area. As example, Indonesian already ratified CRPD which focused on equal rights and protection of disabled persons, but there are $68 \%$ cases which are not informed to have legal assistance during the criminal justice process (MaPPI-FHUI, 2016). Therefore, there is still the missing link between legal formal with the implementation in the practice area - one of the major problems is the lack of knowledge and understanding to disabled people.

In Yogyakarta, Civil Society Organization (CSO) has a significant role to increase understanding of disabled issues. As example, Sasana Integration and Advocacy of Disabled (Sigab) developed an inclusive village project in Yogyakarta. They provide education and socialization of disabled issues within village's community. Another example, Pusham UII have developed the curriculum and module to provide training for legal institution (Police, Prosecutor, and Judge).

\section{THE CULTURAL OF UNDERSTANDING TO DISABLE PEOPLE}

According to the data of the World Bank (WB), there are one billion people have some experiences of diffability, and it was estimating that $15 \%$ of the world's population, particularly is higher in the developing countries (2017). ${ }^{3}$ Disability/diffability issues is a one of subject of social and political discourse. The disable activist believes that disable is a natural part of human diversity - something that should be valued and respected, rather than feared, pitied, and discriminated (Elizabeth Barnes, 2014). This perspective has a function to reconstructive diffability as not impairment person anymore. Because

\footnotetext{
Indonesia, Act Number 8/2016 regards Disability People, section of consideration.

Ibid, article 1.

http://www.worldbank.org/en/topic/disability/overview , retrieved on 4 May 2017.
} 
the most of people are still concern disable people as a "different person from normal condition" with short-and long-term sickness. ${ }^{4}$

The big question how the impairment concept has existed in our life. In order to answer these question, we should understand the concept of human being. In Indonesian, the religious value is important for Indonesian people, moreover the Indonesian government has declared as a not secular country which is important to analyze the concept of the human being according to religious value. First of all, all of religious in Indonesia never stated that the God created human being in the condition of impairment. The God only distinguished people according to the morality and the behavior of the people. Therefore, the religious value never classifies people from the physical conditions. ${ }^{5}$

Thus, the next question is who is responsible for classifying people based on impairment condition. Furthermore, this condition influenced by the power system in human's circumstances - as for the example, human tends to be the people who have good materials, perfect body, well educated, as well as obtain proper position within the social class (Sorjono Soekanto, 1996). Eventually, the impairment terms initiated by the non-disable person to distinguish and classify people based on physical condition - they have labeled people who have the deficiency of physical, cognitive or mental as the impairment persons.

Charles Taylor (1994) mentioned that our identity is formed by recognition, nonrecognition, or by false recognition. Nonetheless, non-recognition and false recognition emerge harm, oppression, misunderstood, distorted and discrimination. ${ }^{6}$ Mostly, the disable group experienced to be underestimated, discriminated and exclusion. For example, Saphiro (1993) argued that American disable people have gone unnoticed and misunderstood - In some ways, he also mentioned that the disable persons as individuals might be more successful at participating in society that the disable persons as a group. ${ }^{7}$ In this sense, the problem of exclusion for disable group is false recognition or misunderstanding about diffability as a group.

Francis \& Silver (2000) also mentioned there is a survey about social exclusion of minorities, and the interesting fact is the general population has not believed that the disable persons is comparable to the social exclusion of another minority group, such as women, racial and religious minorities. He gave an example in the job listings when a job posted an affirmative action for minority candidates, but the disable people are not included in that job-list. ${ }^{8}$

4 Colin Barnes, Disability Studies and the Academy - Past, Present, and Future (2013), Ars Vivendi Journal, 4 (March 2013), p. 3.

5 Setia Adi Purwanta, "Penyandang Disabilitas (translation: People with Disabilities)" in Eko Riyadi, et al, Vulnerable Groups: Kajian dan Mekanisme Perlindungannya (Translation: Vulnerable Group: Study and Mechanism of Protection), (Yogyakarta: Pusham UII, 2012), p. 260-261.

6 Charles Taylor, Multiculturalism (Examining the Politics of Recognition), (New Jersey: Princeton University, 1994), p. 27.

7 Paul T. Jaeger \& Cynthia Ann Bowman, Understanding Disability (Inclusion, Access, Diversity, and Civil Rights, (London: Praeger Publishers, 2005), p. 129.

8 Ibid. 
This perspective looks disable as weak, needy and dependent - that is assume that disable incapable of getting good jobs, living and participating fully in society. ${ }^{9}$ If disable people perceived as "unhealthy", they potentially isolated by the majority group. M. Oliver (1990) analysed that the conception of difability was conceived and spread out across other cultures and societies - he also added the capitalist societies has a big influence to locate the disable people as the minority group. In the wake of capitalism and modernization. Therefore, the disable people is considered as non-valuable human resource or human capital. The result that disable people is being perceived as marginalized group in the socio-economic structures. There are some of disable people often lack and denied with their human, social and economic rights. These factors generate the exclusivism of disable people.

Although the mainstream society, particularly non-disable people fully accept of disable persons in daily life, but it would be still more valuable non-disable people than disable in socio-economic context. ${ }^{10}$ In this sense, this perspective tends to locate disable people as the charity activities - thus, people who lack ability to work are incapable to actively participate and involve with economic and social activities. Consequently, the mainstream society claim a normalize of their physical and mental conditions will automatically make disable people better off.

The main problem is the disable does not seem to be a natural part of diversity. Paul T. Jaeger (2005) believe there is great diversity among the disable people. He argued that the disable people have different kind of diffability for participating and living in society. Thus, the disable people should develop different skills, perspective, and creativity in dealing with conditions and situations. ${ }^{11}$ Furthermore, they can participate and contribute based on their abilities to a diversity of society. Therefore, the government or society should take into account to the specialty of the disable people and remove the social-barriers for them.

In addition, Kurniawan (2014) mention some group presumably recognized as the part of disable group, namely;
a. The wheelchair users
b. Ambulant disabled
c. The deaf people
d. The blind people
e. The mental retardation
f. People who have limitation in cognitive ability
g. People who has limitation in any abilities
h. The elderly
i. The children

In Indonesia, this issue is important, because most of the Indonesian society still generalize of impairment - they believe disable people unable to participate effectively

\footnotetext{
9 Kathryn Sullivan, The Prevalence of the Medical Model of Disability in Society (2011), (AHS Capstone Projects Paper 13), p. 2.

10 Elizabeth Barnes, Valuing Disability, Causing Disability (2014), The University of Chicago Press Journals Vol. 1 (October 2014), p. 91.

11 Paul T. Jaeger \& Cynthia Ann Bowman. supranote 7.
} 
and independently in development. Then, the social construct of impairment affects that the government and NGOs is failed to address the main reason of the exclusion of disable people within economic, political and social life (Suharto, 2011).

\section{THE SOCIAL MODEL FOR THE DISABLED PEOPLE}

Previously, Indonesian legal system used term "impairment" for people who have physical and mental limitation. This term has received criticism, particularly by human rights activists, because when people still label disabled citizens as impaired, it tends to lead to discrimination. ${ }^{12}$ Hence, the new Indonesian disability act reconstructed this term to be disabled persons following United Nations Convention on the Rights of Person with Disabilities (CRPD).

In this sense, it is important to understand the conceptual distinction between impairment and disability. According to the Union of the Physically Impaired Against Segregation (UPIAS) 1976:

Impairment means is lacking part of or all of a limb, or having a defective limb organism or mechanism of the body. Meanwhile, the disability means is the disadvantage or restriction of activity caused by contemporary.

Paul Hunt on behalf of UPIAS also mentioned that

The disabled people are therefore an oppressed group in society. It is necessary to understand the distinction between the physical impairment and the social situation, called disability of people with such impairment. Thus, we define impairment as lacking part of or all of a limb, or having defective limb; and disability as the disadvantage or restriction of activity caused by a contemporary social organisation which takes no or little account of people who have physical impairments and thus excludes them from participation in the mainstream of social activities. Therefore, physical disability is a particular form of social oppression.

According to the explanation above, the disability terms is emphasized on social reconstruction the meaning of disabled person to focus on limitation of society - to understand and value the abilities to contribute for the disabled people. Meanwhile, the impairment term, mainly focus on deficiency of physical condition. Therefore, the disability term struggles to create a set of goals, through of the disability movement to reconstruct and liberate disabled people from a social oppression. According to the UPIAS' definition that this guide constructs that disable group is a part of the oppressed group - thus, the disable persons have inequality accessibility within society's life, such as public transportation, health service, housing, and education.

Nonetheless, Indonesian activist prefers to use disabled terms rather than disabled disabled comes from "different able", it is totally different to disability which means "dis abilities". This term has struggled to change social perspectives that disabled is not a person who have incapacity to do "normal" activities, but a person who able to do

12 VSO, A Handbook on Mainstreaming Disability, (London: VSO, 2006), p. 16. 
something with different abilities. ${ }^{13}$ For the instance, NurulSaadah is the person who walks by sticks in her hands. It means that she can do "normal" activities like another person but with the different ability - if another people is walking by their feet, but Nurul is walking by the sticks. ${ }^{14}$ Therefore, the concept of "normality" activities comes from the misunderstanding and false recognition by another person.

This term was initiated by Indonesian scholars Mansour fakih and Setia Adi Purwanta $^{15}$ - the term disabled is used not only for naming but also to reconstruct the negative perspective of impairment. Therefore, this paper will be used "diffability" names to replace the normative terms of "disability". Originally, the term of disabled developed as part of a medical model. This approach looks disabled as weak, needy and dependent, and it assumes that disabled are incapable of getting good jobs, living and participating fully in society. ${ }^{16}$

The model of difability are conceptual frameworks to understand difability issues there are two common types are medical model and social model (Katie Sullivan, 2011). Both model provide contrast perspective to figure out for disable people. Therefore, it is important for everyone in order to understand and recognize the disable person as equal person in society. In the late $19^{\text {th }}$ and early $20^{\text {th }}$ century, with the rise of the medical profession, the medical model was dominating views of difability (Midgley, 2009).

Originally, the term difability developed as part of a medical model. The conceptualization of the medical model was to emphasize the health condition of disable people. This model also known as the individual model, which is the underlying cause of the problems on their medical condition or impairment. Therefore, this approach tends to give a solution for normalizing their "impairment" with medicalization.

The big assumption of this model if disable people considered 'unhealthy', because that people with their "impairment" is due to the way in which their bodies are shaped and experience. The disable person is generally rejected this model, because this approach generates barriers of natural relationship with their families, communities, as well as society - they also believe that it will be led to their low self-esteem, undeveloped life skills, poor education and high unemployment levels (David Crabtree, 2013).

According to explanation of medical model, that approach generates a negative stereotype for disable people. Every society has social norms that define what that society is and that defines what is desirable and undesirable. ${ }^{17}$ For instance, Philip Selznick argued that community will create a framework of shared beliefs, interests and

13 M. Syafi'ie and Mahrus Ali, Potret Difabel Berhadapan dengan Hukum Negara (translation: Potrait of Disabled within National Law) (Sleman: SIGAB, 2014), p. 11.

14 Choky R. Ramadhan, et al, AnalisisKonsistensiPutusanDifabel (translation: Consistency Analysist of Disabled Judicial Decisions), (Depok: MaPPI-FHUI, 2016), p. 11.

15 Suharto, "Community-based Empowerment for Advocating Diffability Rights (2011) in Dev ISSues Volume 13/01/May 2011, p. 12.

16 Kathryn Sullivan, The Prevalence of the Medical Model of Disability in Society, (2011 AHS Capstone Projects Paper 13), p. 2.

17 Marie Mercat-Bruns, Antidiscrimination Models and Enforcement, (University of California Press, 2016), p. 30. 
commitments that establish into a common faith, a personal identity, a sense of belonging and supportive structure of activities and relationship. In this sense, we think about law in that sense as expressing the social norms of a particular culture and historical moments - laws instantly reinforce to community for sharing world of common faith - they will characteristically to enforce norm for defining their individual and social identity. ${ }^{18}$

Previously, Indonesian legal system used term "impairment" for people who have physical and mental limitation. ${ }^{19}$ That act is considered not relevant anymore - the fundamental problems of disable people are lack comprehension of society or officers to understand the value and existence of disable as the equal citizens. The predominant policy of diffability has been focusing in the charity program - the disable people is recognized as the weak and needy persons.

This approach affects to any aspects either to social policy, as well as legal policy. In the legal policy, the disable people have no equal opportunities and rights with other people. Furthermore, the disable people only have an opportunity to get education and work according to the specific kind and level of their impairment. ${ }^{20}$ It means, they will have difficulties if they want to get education and with non-disable people in the same area - In this sense, however, totally different with the social model which focus on eliminating the social barriers. Therefore, this perspective only emphasizes the disable people is the barriers instead of the social and environment.

In this model, society apparently difficult to accept disable people. If the disable people who considered as "unhealthy" persons, they should be recover themselves with treatment or/and rehabilitation. In this sense, people should adapt by themselves for existing and participating in society. Moreover, the mainstream society only focus and generalize disable person in the same standard, that makes this model potentially generate negative stereotype. It is so easy to see the impact of negative stereotype that construct the disable people to be marginalized group. Frequently, this perspective does not genuinely identify disable person as such. In order to determine disable persons, we should think of the cultural of disable persons are unique and diverse.

At the same time, medical personnel play a major role with respect to the medical elements of the various disability standards (Frank S. Bloch, 1992). Medical personnel should have primary responsibility for identifying medical issues of disable persons. Active involvement of the medical profession in the disability determination process will be beneficial to give greater confidence in decision which relates to the disable persons. ${ }^{21}$ In spite of, the medical model generates a false recognition for disable people, however medical intervention still plays an important role in identifying the needs and barriers of disable people. In this sense, the main problem of the medical model is not talking about medical treatment for disable people, but the perspective to

18 Ibid.

19 Indonesian Act Number 4/1997 regarding the Impairment People mentioned Impairment people is every person who has incapacity in physical and mental, therefore it could be their barriers to properly participate and life.

20 Indonesian Law Number 4/97 regarding the impairment people, article 11-13.

21 Frank S. Bloch, Disability Determination (the Administrative Process and the Role of Medical Personnel), (London: Greenwood Press, 1992), p. 113. 
generalize all of disable persons are unhealthy and the solution only goes to normalize their deficiency.

Since the 1960s, some of disable people involved with the "radical disability movement" in the United Kingdom (UK) and United States (US) (Raymond Lang, 2007). They genuinely rejected the concept of disablement with socio-political perspective, particularly stereotype that disable as the "unhealthy" persons. They argued that disable people were disadvantaged not because of their impairment, but as the false recognition/misunderstanding of social, cultural, economic, and environmental limits to disable people.

This new perspective was part of a social model rather than the original medical model. This model inspired by The Fundamental Principle of Disability ${ }^{22}$ - The social model emphasis into the rights and the requirement for society to accept disable persons. Social model has been known as a part of socio-politics movement in the disable discourses as citizenship rights. ${ }^{23}$ David Crabtree (2013) argued that social model has fundamental principle, that is,

Disability: The loss or limitation of opportunities to take part in society on an equal level with others due to social and environmental barriers. Disability is shown as being caused by 'barriers'or elements of social organization which takes no or little account of people who have impairments.

The social model also urges the new idea that disable people should independently decide for their own lives (Bill Albert, 2014). This approach fundamentally focuses on removing of disabling barriers, as well as emphasize on human rights perspective. This perspective is perceived that society as the main reason of limited accessibility for disable people. ${ }^{24}$ Thus, the primary focus of social model on the economic, environmental, and cultural barriers encountered to the negative stereotype of impairment (Mike Oliver, 2004). As an example, people who cannot walk by their own self are not mean they are impairment, but because society does not accommodate ramp as accessibility in the public transportation. The main point is government and society should start to change a perspective to understand and recognize disable as equal persons.

Nevertheless, there are critics to the social model. Particularly this model presumably ignores the reality that impairment in disable discourse. Tom Shakespeare mentioned that some of disable people still need a medical support - there are some conditions potentially may have premature death, or any condition which involves pain for disable people. ${ }^{25}$ Although this approach was arisen to challenge the medical approach, however the social model is not totally reject the medical intervention.

This model also realizes that there is some condition the disable people need a medical treatment - it could be stressed that social model is rejecting the medicalization

22 This Principle was arranged by The Union of the Physically Impaired Against Segregation (UPIAS)

23 Choky Ramadhan, et al, supranote 14, p. 15.

24 Ibid.

25 Tom Shakespeare, 'the social model of disability', online: https://www.academia.edu/5144537/The_social_model_of_disability. 
of disable people, not rejecting the medical intervention (Bill Albert, 2004). In addition, this perspective is not genuinely denial that medical intervention can be necessary and important for the improvement of the lives of disable people. Therefore, people should not truly have presented the medical model and social model as dichotomous - both of the perspectives, however, should be viewed and understood as the balanced approach to the different aspects and needs of the diffability. ${ }^{26}$

Indonesian disability law is influenced by international human rights discourse. The government tried to follow the concept of social model by the pressure of international communities. The human rights discourse globally arose by the international discourse in the United Nations (UN), especially after the UN enacted the Declaration of Universal Human Rights in 1948. Fundamentally, this declaration guarantees the protection of the "rights and freedoms" to all humans. ${ }^{27}$ Despite, it was not explicitly inserted specific provision on the rights of minorities ${ }^{28}$, including diffability rights.

In the civil rights movements of the 1960's pressured to gain greater accessibility for disable people. ${ }^{29}$ This movement was generated response the Declaration of Universal Human Rights by international communities' movement, particularly Civil Society Organizations (CSO). In 1975, the UN signed the Declaration of the Rights of Disabled Persons which explicitly mentioned that disabled persons have the same civil and political rights as another human being - therefore, the state should protect disable people by the security of economic, social, financial, as well as medical treatment.

Nevertheless, this instrument still considers the disable with the medical problem and depends on the political will of the state to allocate the social security and prosperity for disable people. This approach is totally different with the social model which emphasizes the disable people should be the subject of law and independent to participate in society. Eventually, The UN shows the commitment to strengthen the rights of disable with declare the UN Standard Rules on the Equalization on the Equalization of Opportunities for Persons with Disabilities (1993).

The standard rules are more progressive to ensure full participation and equalization of opportunities for disable people. This instrument realizes the primary obstacles in the fight for equality is the prejudices for the disable people. According to the medical model, the disable person is individuals who have incapacity to perform in any conditions. Therefore, The Standard Rules create and establish the framework to eliminate the barriers to participate in the society. In addition, the Standard Rules targeted at both the individual and the environment (Dimitris Michailakis, 1999).

26 World Health Organization, 'World Report on Disability 2011 ',(2011)online:http://www.who.int/disabilities/world_report/2011/report.pdf?ua=1 , p. 4.

27 Article 1 of the Declaration of Human rights mentioned that "all humans being are born free and equal in dignity and rights. They are endowed with reason and conscience and should act toward one another in a spirit of brotherhood".

28 Julie Ringelheim, Minority Rights in a Time of Multiculturalism-the Evolving Scope of the Framework Convention on the Protection of National Minorities, (Human Rights Law Review 10:1, published by Oxford University Press, 2010), p. 105.

29 C.G.K. Atkins, A Cripple at a Rich Man's Gate: A Comparison of Disability Employment and AntiDiscrimination Law in the United States and Canada, (Canadian Journal of Law and Society Volume 21 No.2, 2006), p. 90. 
Although the UN Member States morally recognized this instrument, the Standard Rules was not completely binding. The characteristic of this Rules is less enforcing than the ratification of a Convention - there is no compliance enforcement, while the Member States fails to implement the Rules into their legal framework. ${ }^{30}$ Therefore, the character of the Standard Rules depends on the strong moral and political commitment of the Member States.

In order to fulfill the necessity of the rights for disable people, the UN enacted the Convention on the Rights of Persons with Disabilities (CRPD) in 2006. However, this convention is a form of the summit of the new perspective of diffability. This convention generally considers the human rights perspective for the disable people, instead of charity based. In the beginning, the idea to create the CRPD was initiated by General Assembly Resolution in 19 December 2001 - the General Assembly Resolution also initiated to create of the Ad Hoc Committee for this issue. Thereafter, the Ad Hoc Committee assigned the CRPD after eight times discussion during July 2002 until December 2006. ${ }^{31}$

This convention ensures and promotes the fundamental human rights and freedoms for all disabled persons without discrimination of any kind. Simultaneously, this Convention urges the Member States to ratify and implement all appropriate legislative, administrative and other measures, as well as to take into account the protection and promotion of the human rights of disable people in all policies and programs. $^{32}$

This convention has general principles shall be: $:^{33}$

a. Respect for inherent dignity, individual autonomy including the freedom to make one's own choices, and independence of persons

b. Non-discrimination

c. Full and effective participation and inclusion in society

d. Respect for difference and acceptance of person with disabilities

e. Equality of opportunity

f. Accessibility

g. Equality between men and women

h. Respect for the evolving capacities of children with disabilities and respect for the right of children with disabilities to preserve their identities.

30 DimitrisMichailakis, "the Standard Rules: A Weak Instrument and a Strong Commitment in Melinda Jones \& Lee Ann Basser Marks, Disability, Divers-ability, and Legal Change, (The Hague: MartinusNijhoff Publishers, 1999), p. 122.

31 FajriNursyamsi, et al, KerangkaHukumDisabilitas di Indonesia: Indonesia Ramah Disabiitas (Translation: The Legal Framework of Disability in Indonesia: Indonesia is Friendly for Disabiliity), (Jakarta: PSHK, 2015), p. 61.

32 The Convention on the Rights of Persons with Disabilities, article 4.

33 Ibid, Article 3. 


\section{THE ROLE OF INDONESIAN CSOS TO ESTABLISHED THE NEW DISABILITY LAW}

Basically, civil society is recognized and dominated by the Non-Government Organization (NGO). Recently, however, civil society is encompassing any actors and entities with a wide range of goals, structures, membership, and geographical coverage, includes; NGOs, professional associations, charitable organizations, indigenous group, faith communities, labour unions and labour organizations, grassroots associations, as well as foundations. ${ }^{34}$

Furthermore, the roles of CSOs are changing at this time. ${ }^{35}$ The increasing global and hyper connected and multi-stakeholders' world influence source of social capital of CSOs world. ${ }^{36}$ Presently, the networked CSO groups are increasingly engaged in partnership with the governments and the private sectors - whilst the most of CSOs might have seen as being opposition with another stakeholder, especially the government and the private sectors in 20 years ago. ${ }^{37}$ Therefore, World Economic Forum (2013) identified roles of CSO encompass;

- Watchdog; holding institutions to account, promoting transparency and accountability

- Advocate: raising awareness of societal issues, challenge and advocating for change

- Service provider: delivering societal needs, including education, health, food and security

- Expert: bringing unique knowledge and experience to shape policy and strategy, and identifying for giving solutions

- Capacity builder: Providing education, training and others

- Incubator: developing solutions that may require a long gestation or payback period

- Representative: giving power to the voice of the marginalized or under-represented

- Citizenship champion: encouraging citizen engagement and supporting the rights of citizens

- Solidarity supporter: promoting fundamental and universal values

- Definer of standards: creating norms that shape market and state activity

In Indonesia, there are international, national, and the disabled persons' organizations (DPO) exist in Indonesia, mainly in Jakarta, Yogyakarta and Solo. DPOs basically followed a traditional model of advocacy, including differing views about national disability strategy, and co-opting by the government officials ${ }^{38}$. In disabled context, however, some people misunderstand and false recognition with physical and

34 World Economic Forum, 'The Future Role of Civil Society', (2014), online:http://www3.weforum.org/docs/WEF_FutureRoleCivilSociety_Report_2013.pdf accessed at 19 July 2017, p. 8.

35 Ibid, p. 9.

36 Ibid

37 Ibid, p. 7.

38 Stephen Meyers, Valerie Karr and Victor Pineda, Youth with Disabilities in Law and Civil Society: Exclusion and Inclusion in Public Policy and NGO Networks in Cambodia and Indonesia, published online on https://disabilityglobalsouth.files.wordpress.com/2012/06/dgs-01-01-02.pdf accessed at 20 July 2017 , p. 22. 
mental condition of disabled. There is still claim disabled people considered as "unhealthy" person. Indonesian activists recently try to challenge the old conception of disability. Following a theory of contestation, this theory basically observes the effects of social practice, by making normative claim. ${ }^{39}$ In the social model which is embedded in United Nations Convention on the Rights Persons with Disabilities (UNCRPD), however, focuses on the inclusion and ensure that the DPOs should be participate in policy decisions.

Therefore, the currently Indonesian activist tried to challenge the new perspective by recognition in the normative discourse. The recognition of disabled as equal person is important, because politics of equal recognition is a part of democracy nowadays, which returned in the form of demands for the equal status. ${ }^{40}$ The increasing awareness may help to reconstruct diffability to diversity issues, rather than being frequently ignored. $^{41}$ According to the Indonesian Constitutional Court's decision ${ }^{42}$, it is mentioned that state should guarantee the constitutional rights, particularly the people who have experienced to be discriminated, excluded, restricted, and marginalized. Those experiences either formally or informally derived by the inequality of structural and socio-cultural within private or public sphere. The state should create the affirmative action to open the equal opportunities for them in order to actively participated in public sphere.

This perspective has been dominant approach until Indonesia ratified the CPRD in 2011. It means that Indonesia shows the commitment to develop a legal framework for diffablity people according to the values, principal, and perspective from the CRPD. However, this ratification was not successfully implementing in the criminal justice process. In the Indonesian criminal justice system, the disable victim usually difficult to give their testimony to the investigator, because they have difficulties to communicate with the others. The investigator, however, was not trying to assess the needs of the victims, but they prefer to stop the process of investigation (Pusham UII, 2015). In addition, MaPPI-FHUI also found that most of disable have not legal aid during the trial process (2016). ${ }^{43}$ It was happened at that time when disable people recognized as impairment - thus, the general perspective was located disable people in inequality position with non-disable persons.

The problems that Indonesian government has not tried to amend the Act of Impairment People - the government naturally consider the implementation already finished when they have successfully ratified the convention. Nevertheless, the cultural of society and officials have not changed to recognized disable as the equal people. However, law has function to transform social norms as well. Marie Mercat-Bruns think

39 Antje Wiener, 'A Theory of Contestation - A Concise Summary of its Argument and Concepts', (Polity Volume 49, Number 1, January 2017), published online January 5, 2017 http://www.journals.uchicago.edu/doi/10.1086/690100.

40 Charles Taylor, Multiculturalism (Examining the Politics of Recognition), (New Jersey: Princeton University, 1994), p. 27.

41 Paul T. Jaeger \& Cynthia Ann Bowman, supranote 7, p. 103.

42 Indonesian Constitutional Court Decision Number 143/PUU-VII/2009, p. 68.

43 This statement according to the data of MaPPI-FHUI, they found there are $41 \%$ cases without legal aid between 2011-2015. 
that law simply as the reflection of the norms of culture. In this sense, law could take a role as a way of changing the culture by which persons act, for example by the lawmaker. ${ }^{44}$

In order to reconstruct that perspective, the Civil Society Organizations (CSO) tried to establish the working group to advocate this issues into legislation discourse. The role of Indonesian activist to promote social model is very important. Activists who collaborated in Civil Society Organization (CSO) play a vital role in the politics of international society movement - CSOs can help to create a norm and development program. ${ }^{45}$ They can create a "non-official law" which is aimed at supplement of expressing the needs of individuals and groups more directly and more generally than official law. ${ }^{46}$

Lesson learned by International experiences - In 1997, international communities reiterated Art. 1 para. 2 of the Protocol Additional to the 1949 Geneva Convention on War Victims - In this case, the state has pressured by the demands of the people with advanced political movements and enlightened public opinion ${ }^{47}$. This demand was played-well by society and CSOs - The essential learned by this case is CSO, and national political movement have strong influenced to contribute the realization of human rights principle when the Government perceived failure to achieve these values. $^{48}$

The Indonesian working group basically response and push the government to adopt the CRPD into the Indonesian diffability law. They have a crucial role to engage with the legislation body in the course of legislation process - Fajri Nursamsyi (2017) explained that Indonesian CSOs have successfully created the research paper regarding social model perspective, and lobbied with the legislative assembly. ${ }^{49}$ The Indonesian disable activist successfully shares the experiences regarding the difficulties to participate in daily activities by themselves.

They mentioned that disable is a part of human diversity, but impairment is the only of generalization to the people who have a deficiency in some conditions. In addition, they also mentioned that all human potential to be impairment - for instance, the elder people possibly difficult to walk because their physical condition is not as strong as previously. In addition, Indonesian activist also emphasized that everybody should take into account the problems of social barriers to disable people - they argued that everyone is potentially became disable. As an example, when people became older, they will have reduction of their power or ability to do some activities. Moreover,

44 Marie Mercat-Bruns, supranote 17, p. 31.

45 Andrew Hurrell, "Power, Principles, and Prudence: Protecting Human Rights in a deeply divided World" in Tim Dunne \& Nicholas J. Wheeler, Human Rights in Global Politics, (New York: Cambridge University Press, 1999), p. 278.

46 Antonio Cassese, "Progressive Transnational Promotion of Human Rights" in B.G. Ramcharan, Human Rights (Thirty Years After the Universal Declaration), (The Hague: MartinusNijhoff Publishers, 1979), p. 260.

47 Ibid,p. 251.

48 Ibid, p. 261.

49 Interview with Fajri Nursyamsi (Researcher of Center Study of Legal Policy) in 25 April 2017. 
people is potentially had injury in any condition. Therefore, the issue of diffability should be important to discuss in national policy discourse.

After the demands by any parties, mainly by the disable communities and Indonesian CSOs, the Indonesian government finally amend the new Indonesian disability law in early 2016. This law successfully replaces the old law and reconstruct the new concept of social model's perspective. This model emphasized the equality rights for disable people. In this sense, the new disability law reconstructs the different approach rather than the previous one. Firstly, this law reconstructs the term of impairment to be disability, it means the concept of diffability is not accordingly emphasized on the health condition anymore, but focus onto the reconstructive of the social barrier instead.

In order to comply the new perspective, this law fundamentally guarantees the respectful, eliminate discrimination, fully participation, diversity, equal opportunity, equality, accessibility, inclusivity, the protection, as well as autonomy of individual. Furthermore, the purpose of this law is reconstructing the perception of diffability is dependent people, and try to ensure that disable people could be independently live and participate in the social activities. This law also essential to protect disable people in the criminal justice process, because there is no explicit provision regarding their rights on the previous law. In the new law, it expressly mentions their rights to the protection of the law and access to justice - the disable people finally have a right in some issues, which is: 50

a. Equality before the law

b. Recognize as the subject of law

c. Own and inherit of the property

d. Independently control the finance, or appoint the agency

e. Obtain an accessibility in the banking and finance service

f. Obtain an accessibility in the access of justice

g. The protection of the pressure, violence, discrimination, oppression, and deprivation

$\mathrm{h}$. Appoint the agency regarding the civil rights issues

i. The protection of intellectual property rights.

\section{THE ROLE OF YOGYAKARTA CSOS TO IMPLEMENT THE SOCIAL MODEL IN LAW ENFORCEMENT INSTITUTIONS}

In Yogyakarta, the local CSOs has significant influence to implement social model in legal institutions. This paper will take place in Yogyakarta (Indonesia) because there are ongoing projects from Sigab and Indonesia Islamic University (Pusham UII) to increase understanding for the government on disabled people. ${ }^{51}$ Sigab is well-known Indonesian Non-Governmental institution which focused to advocate and defend on disabled issues

50 Article 9 of the Indonesian Act Number 8/2016 regarding the Disability People.

51 Pusham UII developed the training for Indonesian law Officer in Yogyakarta. The training has focus of human rights for Disabled people. And Sigab also develop some projects, such as "Inclusive Village" to increase understanding and engage disabled community to participate in social activities. 
since 2003. Furthermore, Pusham UII is one of university research institution who have expertise in human rights issues.

M. Syafi'ie (2014) mentioned there are problems in each criminal justice's process that problems are: (1) lack of sensitivity and understanding within Indonesian law (2) Indonesian law officer is not progressive to handled disabled people (3) minim accessibility within Indonesian judicial facilitation, and (4) the weakness of Indonesian legal culture. Those problems eventually generate discrimination, as well as unfair trial treatment for disabled people in the criminal justice system. The understanding of disabled people is significantly to find out justice in any cases. There is assumption that disabled people afraid and confused to give a testimony of criminal cases, because they fear and difficult to communicate with law officer. Apparently, the law officer misunderstands with the conception of Indonesian criminal procedure law. This law mention that witness is the person who sees, listen, and experience the case. ${ }^{52}$ Thus, if the disabled persons became the victim on the case, they will be had difficulties to give a testimony, because the law officers apparently think that the law is counting the witness as the cumulative circumstances. ${ }^{53}$ Consequently, the deaf and blind people will be difficult for giving testimony during the criminal justice process. Thus, it is important to eliminate obstacle during the criminal justice for the disabled people.

EkoRiyadi (2017) analyzed that there are two barriers in the Indonesian criminal justice, such as the knowledge of the law officers and the facilitation of the judicial institutions. Purwanti (2017) mentioned there are four problems that she faced during her experienced, these are the content of law, the procedure of criminal process, the accessibility, and the perspective of the law officers. Purwanti also mentioned that most of the disable people have no bravery to tell what happens of them. Moreover, they have more difficulties access to communicate with others people. The disabled people still difficult to have an accessibility as same as standard with the "able-bodied" people.

Generally, there are misunderstanding between the communication of disabled people and law officer - in some cases, the law officers did not process the cases because they were apparently difficult to reconstruct cases which involved disabled people. The main reason is difficult to have a well-communicate with disabled people, especially disabled who have deficiency in mental ability. ${ }^{54}$ Therefore, the understanding of the disable issues is really important for handling the disable people in the criminal process.

However, the law officers apparently have difficulties to apply it to the practice area. Muhammad Buchary Kurniata Tampubolon (Ata) believed the mindset perspective of the judges is different when it is regarding diffability issues. They probably will use the mindset as the non-disable people - for example, in the sexual violence cases, the judges usually ask "why do not you fight back?" or "why do not you run away or scream?" ${ }^{55}$ In this sense, those question are not pertinent to their status as a

52 Indonesian Criminal Procedure Law (KUHAP), article 1 point (26).

53 EkoRiyadi, et al, AksesibilitasPeradilanbagiPenyandangDisabilitas (Translation: The Judicial Accessibility for the Disabled People), (Yogyakarta: Pusham UII, 2015), p. 5.

54 M. Syafi'ie, Purwanti, Mahrus Ali, PotretDifabelBerhadapandenganHukum Negara (translation: Portrait Disabled in Dealing with National Law), (Sleman: Sigab, 2014), p. 20.

55 Interview with Kurniata in 13 July 2017 in Wonosari, Yogyakarta. 
disable person, whereas it will be problem if the victim is a disabled person. If the disable cannot speak or walks, indeed, they will have difficulties to run away, scream, or fight back. Thus, the basic problem is that judges do not have adequate capacity to understand a disabled persons' perspective. Moreover, Indonesian legal policy does not have measures that are directed to the powerlessness based on the disables condition. Consequently, it is dangerous as judges consider powerlessness as a weakness in the face of the aggression - at the expense of the disabled person.

Purwanti believed there is no transformation even though the new disability was enactment in the early 2016. ${ }^{56}$ The problems of disable issues is culturally institutionalized since a long time ago. In this sense, Ata argued the new disability law is very new. The implementation of this law is not going well because the judicial institution has not issued into the internal regulation. It will be relating with the budgetary for the reconstructive the facilitation and training for the law officers as well as the staff of judicial institutions. In the criminal procedure, the new disability has no big impact because the provision regarding the procedure law still using the Indonesian criminal procedure law which is this law is not including the diffability perspective.

In Yogyakarta, however, the roles CSOs has specific role in the policymaking and the implementation process, when the formal institutions rarely take an action for improving the reform of policy and capacity. Eko Riyadi as the director of Pusham UII initiated to engage with the legal institutions. In the last year, he decided to meet the chief of Wonosari ${ }^{57}$ District Court (Ata) as the piloting projects. After the discussion, he thinks that Ata potentially received the idea to improve the accessibility for the disabled people. Eko Riyadi generally identified that the law officers have no capacity and knowledge to handle the cases which involve with the disable people. He mentioned the knowledge encompass the ability to understand either the substance of law or technically to interact and giving service to the disable people. Hence, he believed the importance for increasing the capacity to all of officers in the district court. Technically, Eko Riyadi made a deal with Ata for giving training to all of the judges in the Wonosari district court.

Furthermore, the second problem is the less facilitation of the district court. Ata knowingly realized that the structure of the court's building is inaccessible for the disabled people. As examples, the court's building has no ramp, hand rail, guiding block, special toilet for the disable people, and the braille words. However, Ata said that he has no authority to modify the building and the facilitation - because that authority is on the hand of the Indonesian Supreme Court. In this sense, the cultural bureaucracy of Indonesian judicial institutions is centralistic. Thus, Mr. Eko tried to invite Ata in the discussion meeting which possibly invite the leaders of the supreme court as well. In the first meeting, Mr. Eko invite to Ata in the Focus Group Discussion (FGD) for developing curriculum training module regarding the fair trial for the disable people in the September 2016. During the FGD, Ata has a well-interaction with the disable people, another judge, as well as the supreme court judges. ${ }^{58}$

\footnotetext{
56 Interview with Purwanti in 11 July 2017 in Yogyakarta.

57 Wonosari one of district of Yogyakarta Special Region.

58 Interview with Eko Riyadi in 11 July 2017 in Yogyakarta
} 
This meeting successfully improves the perspective of Ata - he simultaneously realizes the spirit of the DPOs and the importance of this issue for the disable people. In the following meeting, Ata directly mentioned that he will make a commitment to establish the accessibility for the disable people in the Wonosari District Court. He also agrees to make Memorandum of Understanding (MoU) between Wonosari District Court and Pusham UII. During the project, Pusham UII have responsibilities for giving advice regarding the structure of the building. Moreover, Pusham UII also work together with Sigab and PLJ for creating video with the sign language and providing braille guideline in the information front desk office.

In the criminal procedure law, however, the reform of the diffability issues is not significant change. Probably, there only provision regarding the translator for the people who cannot speak and listen. Yet, for some reason, the Indonesian criminal code is hard to cover all of the accessibility for the disabled people - because the disabled people are not only the mute and deaf people, there are any different abilities among the disabled people. Kristanti mentioned there is no specific internal regulation and budgetary regarding to handle the disable people in the prosecution institutions. Therefore, it is important for making the implementation of the new disability law in the internal regulation of the respective legal institutions.

Nevertheless, this problem is not always depending on the willingness of the formal institution. The CSOs can take a role as the paralegal for the disable people.For example, Purwanti (2017) shared her experience when she gave assistance to the disable people in the criminal procedure process. She told that her organization focuses on giving legal aid assistance for the disable people, particularly in the trial process. She realizes that the disable people are difficult to communicate with others, therefore she will try to find out the lawyer, the translator, and the medical expert. She also acts to collect the evidence for defending the disable people during the criminal process. In one case, her organization successfully convince the judge regarding the mental diffability - then, the judge takes her arguments into the judicial decision.

In this sense, Purwanti argued that the diffability issues are not popular issues as general. She tried to compare with the child case, the social movement and the CSOs are really active to pressure the government. Thus, the legal institution has strong willingness to implement in the internal policy. In the diffability issues, she thinks that only the DPOs morally understand the importance of this issues, therefore it is important to engage multi stakeholder for making collective action to participate in any policy decisions regarding the disable issues.

\section{CONCLUSION}

Disabled people as part of minority group have struggled to get recognition for equal rights. The Indonesia Government already reconstructed the terms of impairment for disability in the new disability law which was enacted in early 2016. The disabled activists also reject the medical intervention as the main approach within Indonesian legal policy, they believe this approach tends to generate bad stereotypes that disable are weak and an incapable group for participating equally in society. Therefore, they try 
to promote the social model into the normative legal context. Even though Indonesian government already ratified the CRPD into national legal policy, the disable activist thinks it is not enough to reconstruct the perspective of society as well as the officials.

In accessibility, however, the main problem is relating with the content of law, the procedure of criminal process, the accessibility, and the perspective of the law officers. Purwanti believed there is no significant transformation, even though the new disability was enactment in the early 2016. In this sense, Kurniata argued the new disability law is very new, but the cultural perspective of diffability is institutionalized for some time. The implementation of this law is not going well because the judicial institution has not issued it in the internal regulation. It relates with the budget for reconstructing the facilitation and providing training for law officers as well as the staff of judicial institutions. In the criminal procedure, the new disability does not have impact because the provision regarding the procedure law still using the Indonesian criminal procedure law which is this law that is not included in the diffability perspective - especially for the mental diffability.

The process of dialogue between government and disabled communities should start to open - because affirmative action tools have proved to be much more effective in actually bringing a critical mass of people representing minorities. ${ }^{59}$ For example, the experienced of the Indonesian CSOs when they tried advocacte the new disability law with using the substantive of CRPD. Moreover, the disable activist collaborated as the working group for advocating this issue into the legislative sphere. Eventually, the disable CSOs successfully give research and pressure to Indonesian legislative in order to amend the disability law in the previous year. It is important to change the law for following the needs of society, instead of people should follow the rules which clearly discriminate the human community, including those of disabled groups.

According to the success story of Pusham UII, there are two important things as the lesson learned for implementing national policy in the local level. Firstly, the dialogue process is important for sharing idea together. The process dialogue between Pusham UII and the chief of Wonosari District Court generate the consciousness of the diffability issues for Mr. Ata. Ata consciously understand that equal interaction and accessibility is really crucial. Therefore, it is important to change the law for following the needs of humanity, instead of people should follow the rules which is clearly discriminate as the human community, including the disable group.

Secondly, it is important for getting official approval for the diffability issues. Although, there is success story of Wonosari District Court, people should realize that the success story only happen in one district court. The diffability issues should be spreading into all of judicial institutions. According to the Ata's story, he tried to implement the social model after meeting with some key persons in the Indonesian Supreme Court. Even, there is no official approval, but the moral support of the key persons has big influence to Mr. Ata for implementing the improvement facilitation in his district court. Therefore, the cultural bureaucracy of Indonesian depends on the central institutions. Kristanti also thinks that it will be better if the legal institution regulates the technical guideline into their internal regulation.

${ }^{59}$ Ibid, p. 60. 


\section{BIBLIOGRAPHY}

\section{Books}

Bloch, Frank S. (1992) Disability Determination (the Administrative Process and the Role of Medical Personnel). London: Greenwood Press.

Clements, Luke and Janet Read (2008), Disabled People and the Right to Life (the Protection and Violation of Disable People's Most Basic Human Rights, New York: Routledge.

Dunne, Tim and Nicholas J. Wheeler (1999), Human Rights in Global Politics. New York: Cambridge University Press.

Jaeger, Paul T. \& Cynthia Ann Bowman (2005) Understanding Disability (Inclusion, Access, Diversity, and Civil Rights. London: Praeger Publishers.

Jones, Melinda \& Lee Ann Basser Marks (1999) Disability, Divers-ability, and Legal Change. The Hague: MartinusNijhoff Publishers.

Kymlicka, Will (1995) Multicultural Citizenship (a Liberal Theory of Minority Rights). Clarendong Press \& Oxford University Press.

Nursyamsi, Fajri, et al (2015) Kerangka Hukum Disabilitas di Indonesia: Indonesia Ramah Disabilitas (Translation: The Legal Framework of Disability in Indonesia: Indonesia is Friendly for Disabiliity). Jakarta: PSHK.

Pakes, Francis (2010) Comparative Criminal Justice (second edition). Portland: Willan Publishing.

Ramadhan, Choky, et al (MaPPI-FHUI) (2016) Analisis Konsistensi Putusan Difabel (translation: Consistency Analysist of Disabled Judicial Decisions). Depok: MaPPIFHUI.

Ramcharan (1979), Human Rights (Thirty years After the Universal Declaration). The Hague: MartinusNijhoff Publishers.

Syafi'ie, Muhammad and Mahrus Ali (2014) Potret Difabel Berhadapan dengan Hukum Negara (translation: Potrait of Disabled within National Law). Sleman: SIGAB.

Taylor, Charles (1994) Multiculturalism (Examining the Politics of Recognition). Princeton University.

VSO (2006) A Handbook on Mainstreaming Disability. London: VSO.

\section{Journals}

Albert, Bill (2004) Briefing Note: The Social Model of Disability, Human Rights and Development. Disability KaR Research Project. 
The Role of Indonesian CSOS

Atkins, C.G.K. (2006) A Cripple at a Rich Man's Gate: A Comparison of Disability Employment and Anti-Discrimination Law in the United States and Canada. Canadian Journal of Law and Society Volume 21 No.2, 2006.

Barnes, Colin (2013) Disability Studies and the Academy - Past, Present, and Future, Ars Vivendi Journal No.4 (March 2013).

Barnes, Elizabeth (2014) Valuing Disability, Causing Disability. The University of Chicago Press Journals Vol. 125, No. 1, October 2014.

Suharto (2011), Community-based Empowerment for Advocating Diffability Rights in Dev ISSues Volume 13/01/May 2011.

Sullivan, Kathryn Sullivan (2011) The Prevalance of the Medical Model of Disability in Society. 2011 AHS Capstone Projects Paper 13.

\section{Statutes}

Indonesia, Act Number 8/2016 regards Disability People.

International Covenant on Civil and Political Rights.

Convention on the Rights Person with Disabilities.

\section{Internet}

Crabtree,

David

(2013)

Models

of

Disability,http://englishagenda.britishcouncil.org/sites/ec/files/Models\%20of\%20disabil ity.pdf

Meyers, Stephen, Valerie Karr and Victor Pineda (2014) Youth with Disabilities in Law and Civil Society: Exclusion and Inclusion in Public Policy and NGO Networks in Cambodia and Indonesia, published online on https://disabilityglobalsouth.files.wordpress.com/2012/06/dgs-01-01-02.pdf

Shakespeare,Tom the social model of disability, is accessed in https://www.academia.edu/5144537/The_social_model_of_disability

Wiener, Antje (2017) A Theory of Contestation - A Concise Summary of Its Argument and Concepts. http://www.journals.uchicago.edu/doi/10.1086/690100

http://www.worldbank.org/en/topic/disability/overview

World Economic Forum (2013) The Future Role of Civil Society, http://www3.weforum.org/docs/WEF_FutureRoleCivilSociety_Report_2013.pdf

Dio Ashar Wicaksana studied Bachelor of Law at Faculty of Law, University Indonesia, and then took the master degree in sociology of law at Oñati International Institute Sociology of Law. He worked as researcher at Indonesian Judicial Monitoring Society, Faculty of Law University of Indonesia (MaPPI-FHUI) since 2012 until present. He is 
researcher who has expertise in judicial reform and attorney general office or prosecutor reform. He was also actively involved in NGO's coalition, such as court monitoring coalition that consist of Indonesia Corruption Watch (ICW), Indonesia Legal Aid Foundation (YLBHI), Center of Law and Policy Study (PSHK). He was involved in many advocacies for judicial reform issues, as well as fair trial treatment with Indonesia legal system. 